\title{
Concentration effects of grape seed extracts in anti-oral cancer cells involving differential apoptosis, oxidative stress, and DNA damage
}

\author{
Ching-Yu Yen ${ }^{1,2}$, Ming-Feng Hou ${ }^{3,4,5}$, Zhi-Wen Yang ${ }^{6}$, Jen-Yang Tang ${ }^{3,7,8}$, Kun-Tzu Li ${ }^{9}$, Hurng-Wern Huang ${ }^{10}$, \\ Yu-Hsuan Huang ${ }^{6}$, Sheng-Yang Lee ${ }^{11}$, Tzu-Fun Fu ${ }^{12}$, Che-Yu Hsieh ${ }^{9}$, Bing-Hung Chen ${ }^{6 *}$ and Hsueh-Wei Chang $3,9,13,14^{*}$
}

\begin{abstract}
Background: Grape seeds extract (GSE) is a famous health food supplement for its antioxidant property. Different concentrations of GSE may have different impacts on cellular oxidative/reduction homeostasis. Antiproliferative effect of GSE has been reported in many cancers but rarely in oral cancer.

Methods: The aim of this study is to examine the antioral cancer effects of different concentrations of GSE in terms of cell viability, apoptosis, reactive oxygen species (ROS), mitochondrial function, and DNA damage.

Results: High concentrations (50-400 $\mu \mathrm{g} / \mathrm{ml}$ ) of GSE dose-responsively inhibited proliferation of oral cancer Ca9-22 cells but low concentrations $(1-10 \mu \mathrm{g} / \mathrm{ml})$ of GSE showed a mild effect in a MTS assay. For apoptosis analyses, subG1 population and annexin V intensity in high concentrations of GSE-treated Ca9-22 cells was increased but less so at low concentrations. ROS generation and mitochondrial depolarization increased dose-responsively at high concentrations but showed minor changes at low concentrations of GSE in Ca9-22 cells. Additionally, high concentrations of GSE dose-responsively induced more $\mathrm{YH} 2 \mathrm{AX}$-based DNA damage than low concentrations.
\end{abstract}

Conclusions: Differential concentrations of GSE may have a differentially antiproliferative function against oral cancer cells via differential apoptosis, oxidative stress and DNA damage.

Keywords: GSE, Apoptosis, Oxidative stress, DNA damage, Oral cancer

\section{Background}

Betel quid chewing is one of the main causes leading to oral cancer in Taiwan [1]. Arecoline, one of main effective components in betel quid, was reported to lead to DNA damage and apoptosis through the formation of reactive oxygen species (ROS) and contribute to oral carcinogenesis [2-5]. Therefore, the modulation of ROS level may be helpful for oral cancer prevention and therapy.

Grape seed extract (GSE) is a common dietary health supplement due to its natural ROS modulating ability [6]. Commercial preparations of GSE are marketed in the world as a dietary health supplements due to their

\footnotetext{
* Correspondence: bhchen@kmu.edu.tw; changhw@kmu.edu.tw

${ }^{6}$ Department of Biotechnology, Kaohsiung Medical University, Kaohsiung, Taiwan

${ }^{3}$ Cancer Center, Kaohsiung Medical University Hospital, Kaohsiung Medical University, Kaohsiung, Taiwan

Full list of author information is available at the end of the article
}

natural free radical scavenging ability [6]. The cancer chemoprevention and anticancer potential of GSE has been well reviewed previously [7] including skin, colorectal, prostate, breast, lung, and gastric cancers. However, the GSE effects with respect to oral cancer cells are less studied as yet.

ROS modulation effect has been well reviewed $[8,9]$. For example, cellular ROS may regulate apoptosis through the mitochondrial pathway [10-13]. Pro-oxidants induce ROS specifically targeting cancer cells, thereby activating signal transduction pathways that are responsible for cell cycle arrest and/or apoptosis [14]. Similarly, GSE was reported to generate a strong superoxide radical-associated oxidative stress and result in the apoptosis of non-smallcell lung cancer cells [15] as well as in the induction of DNA damage [16].

Different concentrations of GSE were reported to generate diverse biological effects in several cancer studies 
[17-20]. For example, high concentrations $(25-100 \mu \mathrm{g} / \mathrm{ml})$ of GSE showed cytotoxicity or antiproliferation of human bladder [17], colorectal [21], and breast [18] cancer cell lines. In contrast, a low concentration $(2.5 \mu \mathrm{g} / \mathrm{ml})$ of GSE was reported to inhibit the micronuclei frequency and ROS generation in a lymphocyte culture, demonstrating that its antioxidant property has a protective effect during oxidative stress [19]. However, more detailed mechanisms between cancer chemoprevention and anticancer effects of GSE in terms of concentration effects remain unclear.

Since GSE is a natural ROS scavenger, we hypothesize that GSE modulates ROS to further regulate proliferation, apoptosis, mitochondrial function, and DNA damage. Since concentration responses of GSE for these regulations may be relevant, in this study we aim to define the critical concentrations that may or may not be able to induce apoptosis in oral cancer cells.

\section{Methods}

GSE source

The IH636 premium grade proanthocyanidin grape seed (Vitis vinifera) extract (GSE, commercially known as ActiVin $^{\odot}$ ) was purchased from InterHealth Nutraceuticals Inc. (Benicia, CA, USA), which included $75-80 \%$ oligomeric proanthocyanidins and $3-5 \%$ monomeric proanthocyanidins as described previously [22].

\section{Cell cultures}

Cell lines of human oral gingival cancer Ca9-22 [23] and gingival fibroblast HGF-1 [24] were routinely maintained in DMEM/F12 medium (Gibco, Grand Island, NY) containing 10\% fetal bovine serum, 0.03\% glutamine, $1 \mathrm{mM}$ sodium pyruvate, and penicillin/streptomycin mixtures. Cells were kept at $37^{\circ} \mathrm{C}$ in a humidified incubator containing $5 \% \mathrm{CO}_{2}$.

\section{Determination of cell viability}

Viability analysis was performed using Cell Titer $96^{\mathrm{mm}}$ Aqueous One solution cell proliferation (3-(4,5-dimethylthiazol-2-yl)-5-(3-carboxymethoxyphenyl)-2-(4- sulfophenyl)-2H-tetrazolium) MTS) assay kit (Promega Madison, WI, USA) as described previously [25] with minor modification. In brief, cells were treated with various concentrations of GSE in fresh media in triplicates. The non-toxic concentration of DMSO (less than $1 \% \mathrm{v} / \mathrm{v}$ ) was used to prepare test solutions in all assays. The plates were then incubated for $24 \mathrm{~h}$ under standard growth conditions. Subsequently, MTS reagent was loaded to each well (5 $\mathrm{mg} / \mathrm{ml}$ in PBS) and cells were again incubated for another $2 \mathrm{~h}$. Then, absorbance of each well was recorded directly at $490 \mathrm{~nm}$ by ELISA multi-Plate Reader (MTX Lab Systems, Inc., Vienna, VA, USA).

\section{Determination of sub-G1 population}

Measurement of DNA content for cell cycle analysis were carried out by flow cytometry, based on a previously described protocol [26]. In brief, Ca9-22 cells were treated with either DMSO only or different GSE concentrations for $24 \mathrm{~h}$. After incubation, cells were harvested for washing and fixing in $70 \%$ ethanol overnight. After harvest, cells were resuspended in $1 \mathrm{ml}$ PBS containing $10 \mu \mathrm{g} / \mathrm{ml}$ PI (Sigma, St Louis, MO, USA) in the dark. Subsequently, cells were analyzed using a flow cytometer (FACScan; Becton-Dickinson, Mansfield, MA) at excitation and emission settings of 480 and $525 \mathrm{~nm}$, respectively, and Win-MDI software (http://facs.scripps.edu/ software.html).

\section{Determination of apoptosis by annexin V/PI}

The induction of apoptosis by GSE-treated Ca9-22 cells was analyzed by annexin $\mathrm{V}$ staining as previously described [27]. Briefly, cells were treated with either vehicle or various GSE concentrations for $24 \mathrm{~h}$. Subsequently, the cells were trypsinized, washed twice with PBS and stained with fluorescein isothiocyanate (FITC)-labelled annexin V. Then, the samples were measured with a flow cytometer (FACSCalibur; Becton-Dickinson) for the quantification of apoptotic cells at excitation and emission settings of 480 and $525 \mathrm{~nm}$, respectively, and Win-MDI software.

\section{Determination of apoptosis by pan-caspase activity}

The induction of apoptosis by GSE-treated Ca9-22 cells was analyzed by activation of caspases (caspase-1, 3, 4, 5, $6,7,8,9$ ) by the generic caspase activity assay kit (Abcam, Cambridge, UK) as previously described [27]. Briefly, cells were treated with either vehicle or various GSE concentrations for $24 \mathrm{~h}$. After harvest, the cells were suspended and stained with $1 \mathrm{X}$ fluorescent TF2-Val-Ala-Asp (VAD)FMK at the cell incubator for $1 \mathrm{~h}$. Then, the samples were measured with a flow cytometer (BD Accuri C6; BectonDickinson, Mansfield, MA, USA) and a BD Accuri C6 Software (version 1.0.264) for the quantification of pancaspase positive populations at excitation and emission settings of 480 and $525 \mathrm{~nm}$, respectively.

\section{Determination of intracellular ROS}

Intracellular redox state were determined by the ROSsensitive dye $2^{\prime}, 7^{\prime}$-dichlorodihydrofluorescein diacetate (DCFH-DA) (Sigma Chemical Co., St. Louis, MO, USA) as previously described $[25,28]$. Ca9-22 cells were treated with various concentrations of GSE for $24 \mathrm{~h}$. Subsequently, cells were harvested, thoroughly washed, resuspended in $10 \mu \mathrm{M}$ DCFH-DA in PBS and then incubated at $37^{\circ} \mathrm{C}$ for $30 \mathrm{~min}$ in darkness. After incubation, cells were washed, resuspended in PBS, and analyzed with a FACSCalibur flow cytometer at excitation and emission 
settings of 480 and $525 \mathrm{~nm}$, respectively, and Win-MDI software.

\section{Determination of mitochondrial membrane potential} Mitochondrial membrane potential (MitoMP) was determined by flow cytometry using MitoProbe ${ }^{\text {ma }}$ DiOC2(3) assay kit (Invitrogen, San Diego, CA, USA) as described previously [25]. In brief, cells were incubated with various GSE concentrations at $37^{\circ} \mathrm{C}$ for $24 \mathrm{~h}$. Subsequently, cells were incubated in culture medium (containing $50 \mu \mathrm{M}$ of $\left.\mathrm{DiOC}_{2}(3)\right)$ at $37^{\circ} \mathrm{C}$ for $20 \mathrm{~min}$ in an incubator. After washing and resuspension in PBS, cells were subjected to flow cytometric analysis. The fluorescence intensity was measured using 488 and $525 \mathrm{~nm}$ filter settings for the excitation and emission wavelengths, respectively. The data were analyzed with Win-MDI software.

\section{Determination of DNA double strand breaks (DSBs) by $\mathrm{YH} 2 \mathrm{AX} / \mathrm{PI}$ double staining}

DSBs were measured by flow cytometry as described previously [25]. Ca9-22 cells were incubated with various GSE concentrations for $24 \mathrm{~h}$, followed by fixation with $70 \%$ ethanol overnight. After washing twice with BSA-TPBS (1\% bovine serum albumin and $0.2 \%$ Triton X-100 in PBS), cells were treated with $100 \mu \mathrm{l}$ of BSA-T-PBS solution containing $0.2 \mu \mathrm{g}$ monoclonal antibody against p-Histone H2A.X (Ser 139) (Santa Cruz Biotechnology, Santa Cruz, CA, USA) for overnight at $4^{\circ} \mathrm{C}$. After washing, cells were resuspended in Alexa Fluor 488-tagged secondary antibody (Jackson ImmunoResearch Laboratories, Inc., West Grove, PA, USA) at a 1:100 dilution for $1 \mathrm{~h}$ at $4^{\circ} \mathrm{C}$. After washing, cells were resuspended in $1 \mathrm{ml}$ PBS containing $5 \mu \mathrm{g} / \mathrm{ml} \mathrm{PI}$ and analyzed by a FACSCalibur flow cytometer and Win-MDI software.

\section{Statistical analysis}

Statistical analysis was performed with JMP 9 software. One-way ANOVA with Tukey's HSD Post Hoc Test was used to analyze significant differences between treatments. Unless otherwise indicated, all experiments were repeated in triplication.

\section{Results}

\section{Cell viability}

To access the potential harmful effects of GSE on Ca922 cells, cell viability was determined by MTS reagent. At low concentrations of GSE treatment $(1-10 \mu \mathrm{g} / \mathrm{ml})$, the cell viabilities maintained around 91\% (Figure 1). In contrast, a significantly concentration-dependent decrease in cell viability $(P<0.005-0.0001)$ was observed at high GSE concentrations $(50,100,200$ and $400 \mu \mathrm{g} / \mathrm{ml})$. The $\mathrm{IC}_{50}$ of GSE for Ca9-22 cells was $150 \mu \mathrm{g} / \mathrm{ml}$ at $24 \mathrm{~h}$ incubation. However, both the low and high concentrations of GSE were not harmful to normal oral HGF-1 cells.

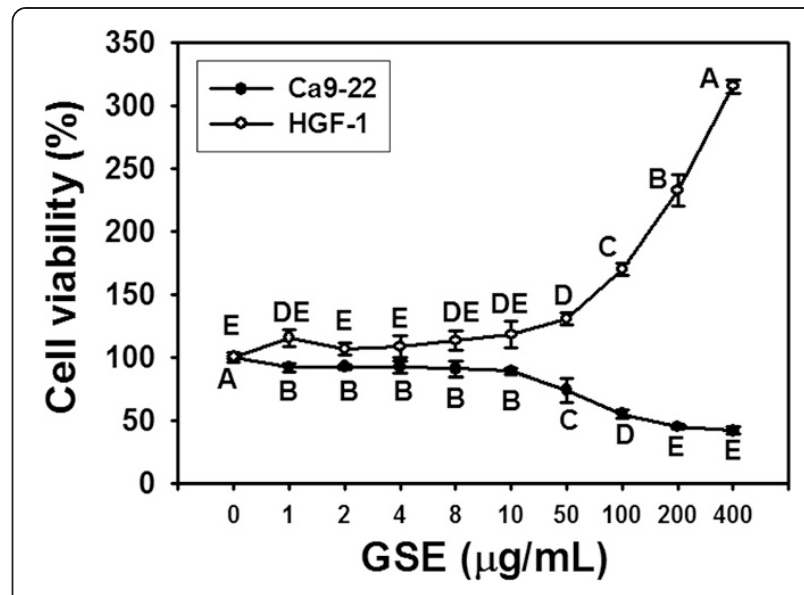

Figure 1 Cytotoxicity of GSE treatments on oral cancer Ca9-22 cells and normal oral HGF-1 cells. Cells were treated with either vehicle control (DMSO) or with 2, 4, 8, 10, 50, 100, 200 and $400 \mu \mathrm{g} / \mathrm{ml}$ of GSE for $24 \mathrm{~h}$. Cell viability was detected by the MTS assay. The percent cell viability in the experimental groups was adjusted to the DMSO-treated group representing $100 \%$ viability. Data, mean \pm SD ( $n=10$ and 5 for Ca9-22 and HGF-1 cells, respectively). Treatments with the same capital letter are nonsignificant.

\section{Cell cycle distribution by GSE treatments}

To investigate if GSE treatments cause change in cell cycle distribution in Ca9-22 cells, a standard PI-staining protocol was applied to GSE-treated Ca9-22 cells. In Figure $2 \mathrm{~A}$, the cell cycle distributions were stable at low concentrations $(1-10 \mu \mathrm{g} / \mathrm{ml})$ of GSE but the subG1 populations were gradually accumulated at high concentrations of GSE. In Figure 2B, the change in the sub-G1 populations (\%) of Ca9-22 cells was not significant at low concentrations of GSE. However, the changes in the sub-G1 populations (\%) significantly increased to 5.61, 16.73, 25.69 and 26.80 in a concentration-dependent manner $(P<0.0001)$ when GSE concentrations were increased at 50, 100, 200 and $400 \mu \mathrm{g} / \mathrm{ml}$, respectively. Additionally, the percentage changes in other cell cycle phases (i.e. the G1, $\mathrm{S}$ and $\mathrm{G} 2 / \mathrm{M}$ phases) did not exhibit significant changes in all treatment groups compared to untreated samples.

\section{Apoptotic cell death: annexin V/PI}

To determine the degree of apoptosis of GSE-induced cell death in Ca9-22 cells, the annexin V-FITC staining was determined by flow cytometry. In Figure 3A, the apoptosis signals were similar at low concentrations $(1-10 \mu \mathrm{g} / \mathrm{ml})$ of GSE but they gradually increased at high concentrations of GSE. In Figure 3B, the annexin V intensity of GSE-treated Ca9-22 cells was weak at low concentrations of GSE. However, the percentage changes in the annexin $\mathrm{V}$ intensity significantly increased to $14.19 \%$, $20.03 \%, 44.53$, and $72.86 \%$ in a concentration-dependent manner at high concentrations (50,100, 200 and $400 \mu \mathrm{g} /$ $\mathrm{ml})$ of GSE $(P<0.05-0.0001)$. 

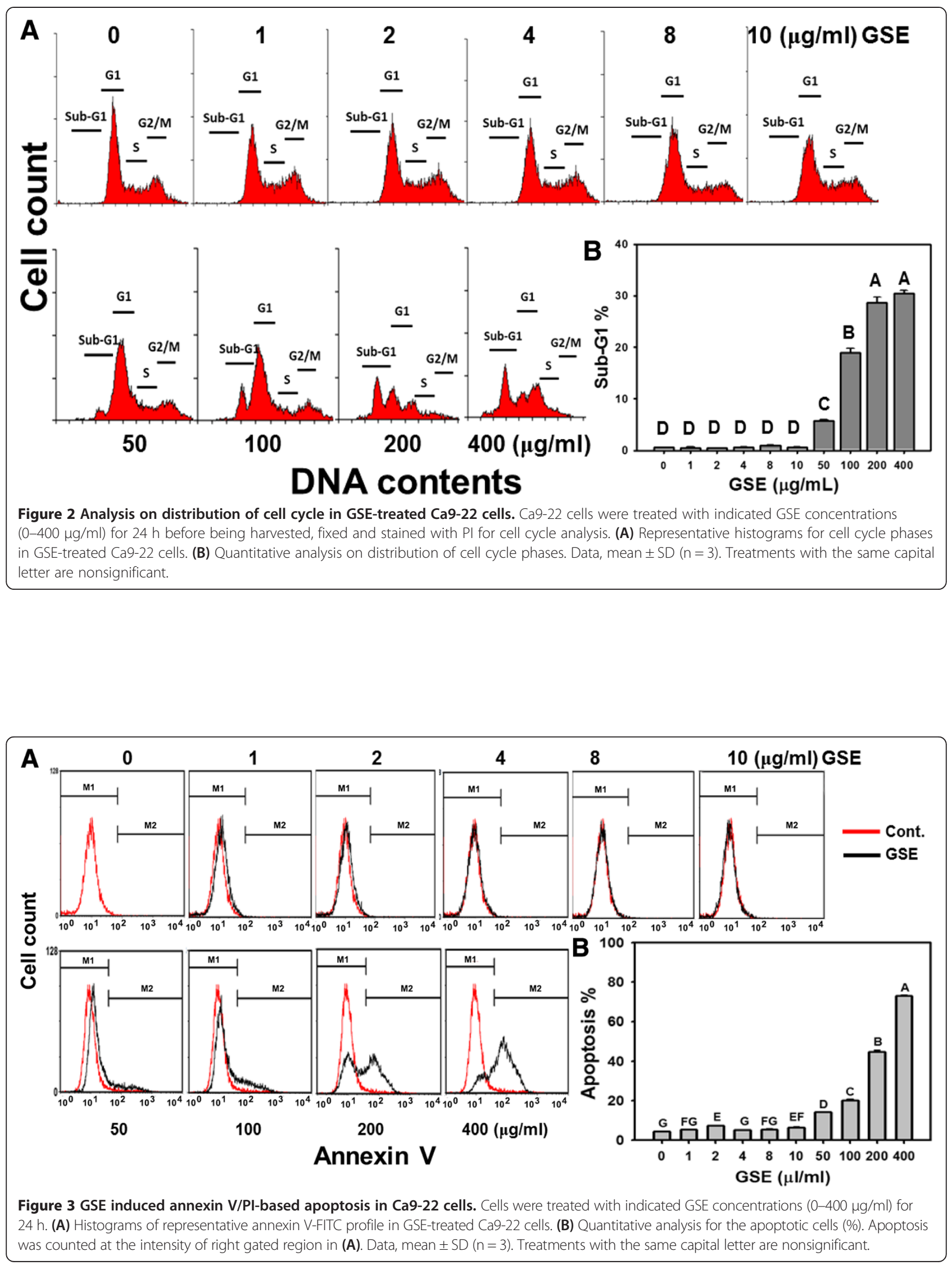
Apoptotic cell death: caspase activity

To further determine the degree of apoptosis of GSEinduced cell death in Ca9-22 cells, the multiple caspase (pan-caspase) activity staining was determined by flow cytometry. In Figure 4A, the apoptosis signals based on pan-caspase intensities were similar at low concentrations $(1-10 \mu \mathrm{g} / \mathrm{ml})$ of GSE but they gradually increased at high concentrations of GSE. In Figure 4B, the pancaspase positive intensity of GSE-treated Ca9-22 cells was weak at low concentrations of GSE. However, the percentage changes in the pan-caspase positive intensity concentration-responsively increased at high concentrations $(50,100,200$ and $400 \mu \mathrm{g} / \mathrm{ml})$ of GSE, respectively $(P<0.01-0.001)$.

\section{Intracellular ROS}

ROS plays a pivotal role in regulating cellular apoptosis. To determine whether Ca9-22 cells exposed to GSE bore higher levels of ROS, we monitored the intracellular ROS levels using the fluorescent dye DCFH-DA as a specific ROS scavenger. In Figure 5A, the ROS signals were similar at low concentrations $(1-10 \mu \mathrm{g} / \mathrm{ml})$ of GSE but they were gradually increased at high concentrations of GSE. In Figure 5B, no significant elevation of ROS levels became apparent in Ca9-22 cells treated with GSE concentrations lower than $10 \mu \mathrm{g} / \mathrm{ml}$. However, after exposing Ca9-22 cells to GSE at 50, 100, 200 and $400 \mu \mathrm{g} / \mathrm{ml}$ for $24 \mathrm{~h}$, the ROS levels increased significantly in a concentration-dependent manner to $2.10 \%, 5.10 \%, 27.77 \%$, and $63.17 \%$, respectively $(P<0.005-0.0001)$.

\section{MitoMP}

To examine the involvement of GSE-induced mitochondrial dysfunction in Ca9-22 cells, the flow cytometrybased Rh123 staining was performed. In Figure 6A, the mitoMP signals were similar in low concentrations $(1-10 \mu \mathrm{g} / \mathrm{ml})$ of GSE but they were gradually decreased in high concentrations of GSE after $100 \mu \mathrm{g} / \mathrm{ml}$ of GSE. In Figure 6B, there was not a significant elevation of mitoMP levels in Ca9-22 cells incubated with GSE concentrations lower than $10 \mu \mathrm{g} / \mathrm{ml}$. In contrast, after exposing Ca922 cells to GSE at 50,100, 200 and $400 \mu \mathrm{g} / \mathrm{ml}$ for $24 \mathrm{~h}$, the mitoMP levels were significantly decreased in a concentration-dependent manner to $101.14 \%, 91.69 \%$, $66.97 \%$, and $15.01 \%$, respectively $(P<0.005-0.0001)$.

\section{DNA damages caused by GSE treatment}

To detect whether GSE treatments cause DNA double strand break (DSB) in Ca9-22 cells, samples were analyzed using flow cytometry to quantify levels of the phosphorylated $\gamma \mathrm{H} 2 \mathrm{AX}$ protein. In Figure $7 \mathrm{~A}$, the $\gamma \mathrm{H} 2 \mathrm{AX}$ signals were similar in low concentrations $(1-10 \mu \mathrm{g} / \mathrm{ml})$ of GSE but they were gradually increased in high concentrations of GSE. In Figure 7B, there was not a significant elevation of $\gamma \mathrm{H} 2 \mathrm{AX}$ levels in GSE-treated Ca9-22 cells under low concentrations (lower than $10 \mu \mathrm{g} / \mathrm{ml}$ ). In contrast, after exposing Ca9-22 cells to GSE at 50, 100, 200 and $400 \mu \mathrm{g} / \mathrm{ml}$ for $24 \mathrm{~h}$, the $\gamma \mathrm{H} 2 \mathrm{AX}$ levels were significantly increased in a concentration-dependent manner to $3.38 \%, 5.88 \%, 19.02 \%$, and $35.53 \%$, respectively $(P<0.001)$.

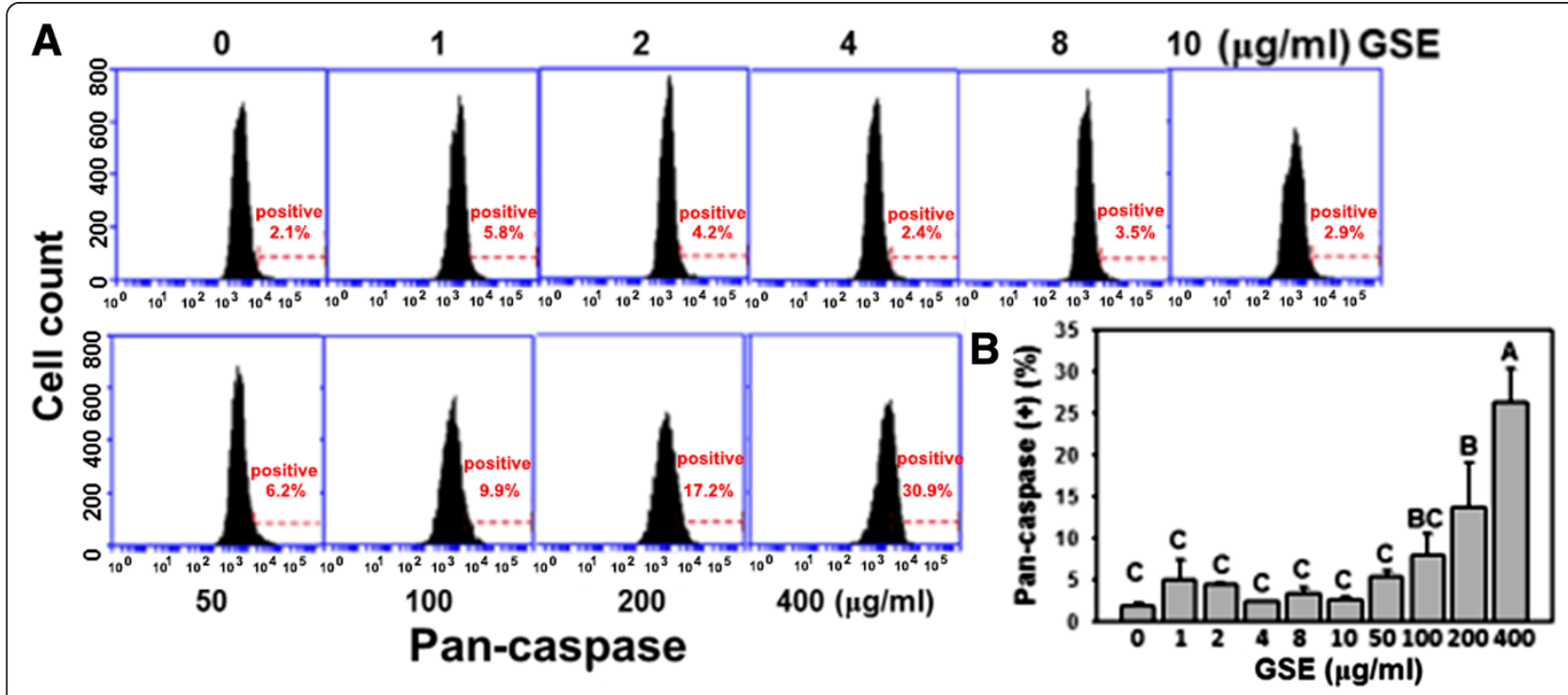

Figure 4 GSE induced pan-caspase-based apoptosis in Ca9-22 cells. Cells were treated with indicated GSE concentrations $(0-400 \mu \mathrm{g} / \mathrm{ml})$ for 24 h. (A) Histograms of representative pan-caspase activity profile in GSE-treated Ca9-22 cells. Caspase positive \% was indicated in the right gated region of each panel. (B) Quantitative analysis for the pan-caspase positive (\%). Data, mean $\pm S D(n=3)$. Treatments with the same capital letter are nonsignificant. 

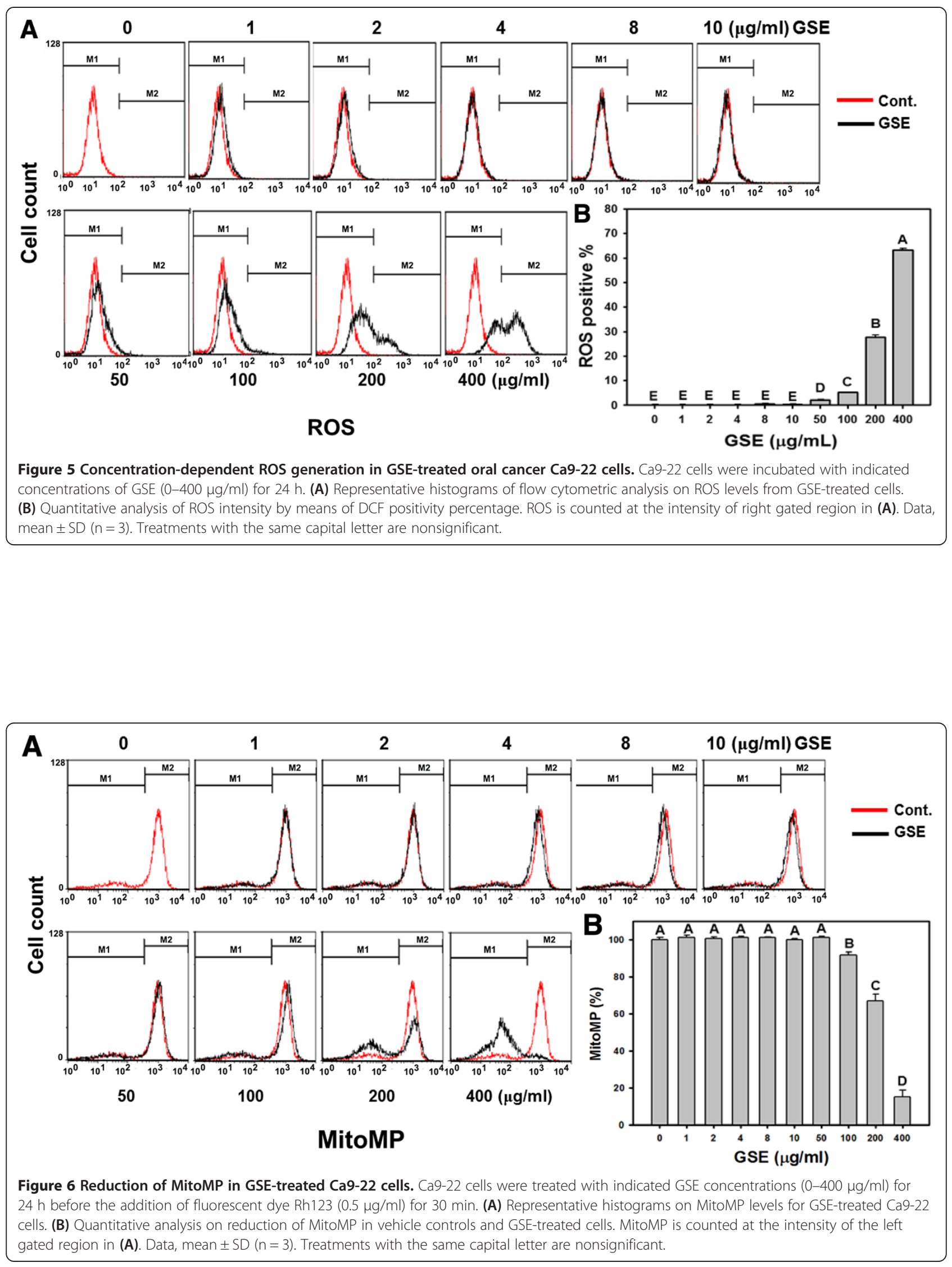


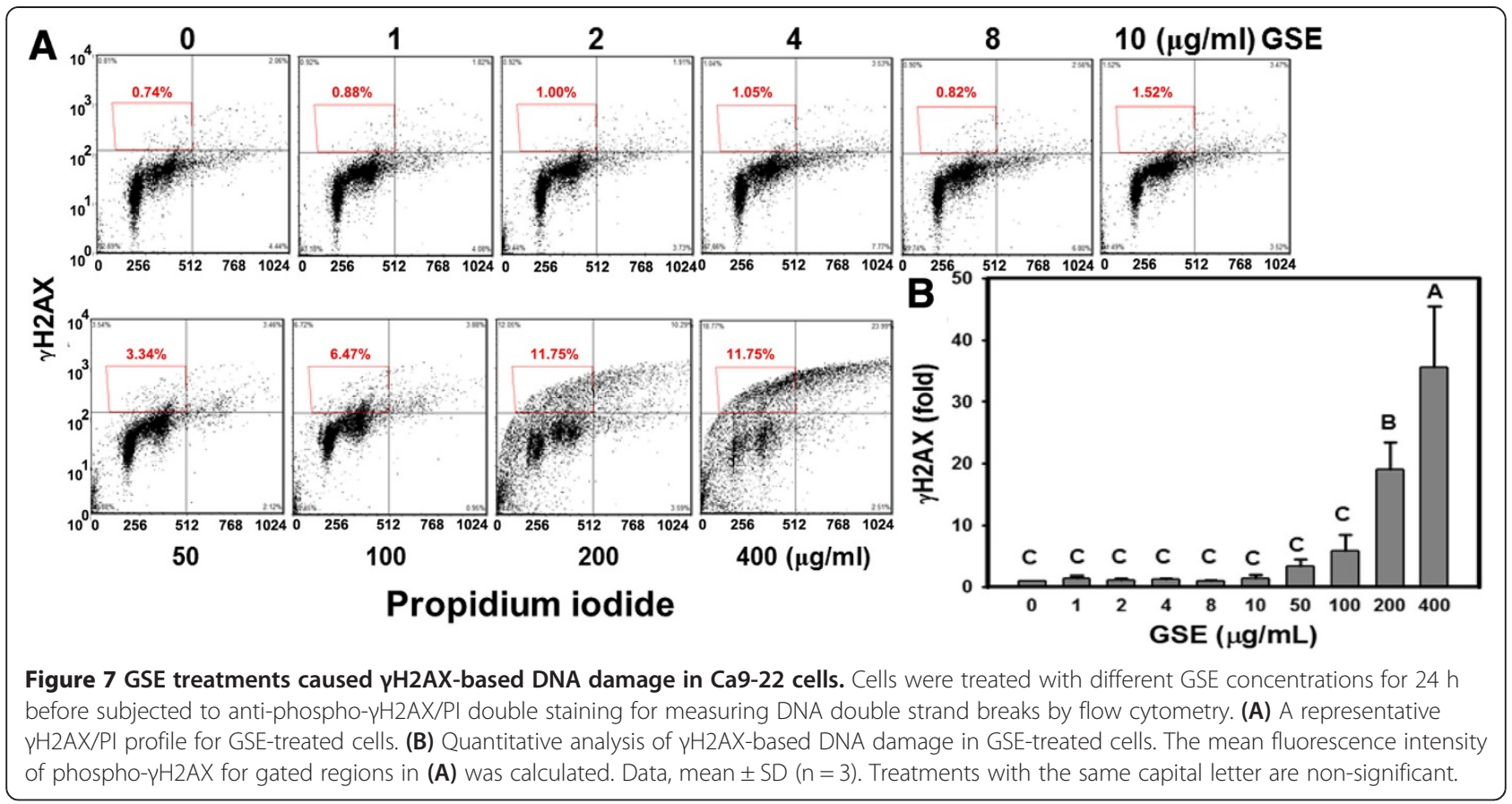

\section{Discussion}

Accumulating evidence of the antiproliferative effect of GSE had been reported in several oral cancer cell lines. For example, high concentrations $(50-600 \mu \mathrm{g} / \mathrm{ml})$ of GSE of Vitis vinifera were found to inhibit cell proliferation and induce apoptosis of the KB cells but less harmful to non-cancerous human umbilical vein endothelial cells (HUVEC) by trypan blue assay at $24 \mathrm{~h}$ GSE treatment [29]. Similarly, we found that the low and high concentrations of GSE to normal oral HGF-1 cells based on MTS analysis. The KB cells was used to be regarded as the oral cancer cell line, however, it was recently confirmed to be the contaminant cervical cancer HeLa cells [30]. Moreover, the low concentrations of GSE were not investigated in this study. Recently, the differential concentration effect of GSE to differentially inhibit proliferation of oral cancer cells has been demonstrated. For example, low concentrations of GSE $(10-20 \mu \mathrm{g} / \mathrm{ml})$ did not displayed the antiproliferation of oral cancer CAL 27 cells but high concentrations of GSE $(30-80 \mu \mathrm{g} / \mathrm{ml})$ were able to inhibit its proliferation [31]. Similarly, we found that low $(1-10 \mu \mathrm{g} / \mathrm{ml})$ and high $(50-400 \mu \mathrm{g} / \mathrm{ml})$ concentrations of GSE displayed the differential cytotoxic effects to cell viability of oral cancer Ca9-22 cells. Similar results also reported in other cancer cells. In the example of skin cancer $\mathrm{HaCaT}$ cells, high concentrations of GSE $\left(\mathrm{IC}_{50}=76.44 \mu \mathrm{g} \mathrm{GAE} / \mathrm{ml}\right)$ displayed the growth inhibitory effect, but low concentrations of GAE (10$20 \mu \mathrm{g} \mathrm{GAE} / \mathrm{ml}$ ) protected against UVB irradiation (50$100 \mathrm{~mJ} / \mathrm{cm}^{2}$ )-induced skin cancer [20]. These findings suggested that different cancer cell lines may require different but high concentrations of GSE for antiproliferation purpose.

ROS induction by GSE was reported in non-small-cell lung cancer H1299 and A549 cells but it only tested at high concentrations $(20-100 \mu \mathrm{g} / \mathrm{ml})$ without detecting the mitochondrial function [15]. ROS generation of high GSE $(40 \mu \mathrm{g} / \mathrm{ml})$ also reported to induce apoptosis in head and neck cancer Detroit 562 and FaDu cells [32]. In oral cancer CAL 27 cells, GSE also reported to induce mRNA overexpression of apoptosis-associated signaling such as caspase-2 and caspase-8 [31]. In head and neck cancer cells, GSE also reported to induce DNA damage [32]. Our results further validated that GSE at high concentrations $(50-400 \mu \mathrm{g} / \mathrm{ml})$ have high oxidative stress and apoptosis in terms of ROS generation, mitochondrial depolarization, annexin V/PI staining, and caspase activation but not for low concentrations $(<10 \mu \mathrm{g} / \mathrm{ml})$ of GSE in oral cancer Ca9-22 cells.

Moreover, this differential concentration effect of GSE was also found in cancer cell migration. For example, GSE was reported to inhibit migration and invasion of breast cancer MDA-MB231 cell [18]. High concentrations (50$100 \mu \mathrm{g} / \mathrm{ml}$ ) of GSE inhibited cell proliferation and induced apoptosis. Conversely, low GSE $(25 \mu \mathrm{g} / \mathrm{ml})$ concentrations decreased cell migration and invasion. Therefore, the differential concentration effect of GSE in oral cancer cell migration is warranted for further investigation.

\section{Conclusion}

We demonstrated that GSE shows differential concentration effects in the antiproliferation of oral cancer cells 
through differential expressions of apoptosis, oxidative stress, and DNA damage. We showed that the antiproliferative effect of high GSE concentrations is associated with an overproduction of ROS causing DNA damage and apoptosis of cancer cells.

\section{Competing interests}

The authors declare that they have no competing interests.

\section{Authors' contributions}

$\mathrm{C}-\mathrm{YY}, \mathrm{M}-\mathrm{FH}, \mathrm{B}-\mathrm{HC}$, and $\mathrm{H}-\mathrm{WC}$ participated in the writing and the study design. J-YT and H-WC performed statistical analysis. Z-WY, K-TL, C-YH, and Y-HH performed survival assay and flow cytometer analysis. H-WH, S-YL, T-FF, B-HC, and H-WC analyzed and discussed the GSE data. B-HC and H-WC coordinated and oversaw the study. All authors read and approved the final manuscript.

\section{Acknowledgements}

This work was partly supported by funds of the Ministry of Science and Technology (MOST 103-2320-B-037-008), the ChiMei-KMU Joint Project (103CM-KMU-09), the Kaohsiung Medical University "Aim for the Top Universities Grant, grant No. KMU-TP103A33", the Kaohsiung Municipal Ta-Tung Hospital (kmtth-102-011), the National Sun Yat-sen University-KMU Joint Research Project (\#NSYSU-KMU 104-p036), and the Health and welfare surcharge of tobacco products, the Ministry of Health and Welfare, Taiwan, Republic of China (MOHW104-TDU-B-212-124-003). We also thank for the help in English editing by Dr. Hans-Uwe Dahms and technical support with the flow cytometer by Mr. Yi-An Chung.

\section{Author details}

${ }^{1}$ Department of Oral and Maxillofacial Surgery Chi-Mei Medical Center, Tainan, Taiwan. ${ }^{2}$ School of Dentistry, Taipei Medical University, Taipei, Taiwan. ${ }^{3}$ Cancer Center, Kaohsiung Medical University Hospital, Kaohsiung Medical University, Kaohsiung, Taiwan. ${ }^{4}$ Institute of Clinical Medicine, Kaohsiung Medical University, Kaohsiung, Taiwan. ${ }^{5}$ Kaohsiung Municipal Ta-Tung Hospital, Kaohsiung, Taiwan. ${ }^{6}$ Department of Biotechnology, Kaohsiung Medical University, Kaohsiung, Taiwan. ${ }^{7}$ Department of Radiation Oncology, Faculty of Medicine, College of Medicine, Kaohsiung Medical University, Kaohsiung, Taiwan. ${ }^{8}$ Department of Radiation Oncology, Kaohsiung Medical University Hospital, Kaohsiung, Taiwan. ${ }^{9}$ Department of Biomedical Science and Environmental Biology, Kaohsiung Medical University, Kaohsiung, Taiwan. ${ }^{10}$ Institute of Biomedical Science, National Sun Yat-Sen University, Kaohsiung, Taiwan. ${ }^{11}$ School of Dentistry and Wan-Fang Hospital, Taipei Medical University, Taipei, Taiwan. ${ }^{12}$ Department of Medical Laboratory Science and Biotechnology, School of Medicine, National Cheng Kung University, Tainan, Taiwan. ${ }^{13}$ Institute of Medical Science and Technology, National Sun Yat-sen University, Kaohsiung, Taiwan. ${ }^{14}$ Research Center of Environmental Medicine, Kaohsiung Medical University, Kaohsiung 80708, Taiwan.

Received: 28 November 2014 Accepted: 21 February 2015 Published online: 29 March 2015

\section{References}

1. Ko YC, Huang YL, Lee CH, Chen MJ, Lin LM, Tsai CC. Betel quid chewing, cigarette smoking and alcohol consumption related to oral cancer in Taiwan. J Oral Pathol Med. 1995;24(10):450-3.

2. Nair UJ, Obe G, Friesen M, Goldberg MT, Bartsch H. Role of lime in the generation of reactive oxygen species from betel-quid ingredients. Environ Health Perspect. 1992;98:203-5.

3. Ji WT, Yang SR, Chen JY, Cheng YP, Lee YR, Chiang MK, et al. Arecoline downregulates levels of p21 and p27 through the reactive oxygen species/ mTOR complex 1 pathway and may contribute to oral squamous cell carcinoma. Cancer Sci. 2012;103(7):1221-9.

4. Lee SS, Tsai CH, Yu CC, Chang YC. Elevated snail expression mediates tumor progression in areca quid chewing-associated oral squamous cell carcinoma via reactive oxygen species. PLoS One. 2013;8(7):e67985.

5. Yen CY, Lin MH, Liu SY, Chiang WF, Hsieh WF, Cheng YC, et al. Arecolinemediated inhibition of AMP-activated protein kinase through reactive oxygen species is required for apoptosis induction. Oral Oncol. 2011;47(5):345-51.

6. Bagchi D, Garg A, Krohn RL, Bagchi M, Tran MX, Stohs SJ. Oxygen free radical scavenging abilities of vitamins $C$ and $E$, and a grape seed proanthocyanidin extract in vitro. Res Commun Mol Pathol Pharmacol. 1997;95(2):179-89.

7. Kaur M, Agarwal C, Agarwal R. Anticancer and cancer chemopreventive potential of grape seed extract and other grape-based products. J Nutr. 2009;139(9):1806S-12.

8. Chang HW. The fate of marine algal natural products-treated cells depend on it ROS modulating effects. J Rashid Latif Med College. 2013;2:8-10.

9. Lee JC, Hou MF, Huang HW, Chang FR, Yeh CC, Tang JY, et al. Marine algal natural products with anti-oxidative, anti-inflammatory, and anti-cancer properties. Cancer Cell Int. 2013;13(1):55.

10. Circu ML, Aw TY. Reactive oxygen species, cellular redox systems, and apoptosis. Free Radic Biol Med. 2010;48(6):749-62.

11. Song W, Hu P, Shan Y, Du M, Liu A, Ye R. Cartilage polysaccharide induces apoptosis in $\mathrm{K} 562$ cells through a reactive oxygen species-mediated caspase pathway. Food Funct. 2014;5(10):2486-93.

12. Cheng AC, Tsai ML, Liu CM, Lee MF, Nagabhushanam $K$, Ho CT, et al. Garcinol inhibits cell growth in hepatocellular carcinoma Hep3B cells through induction of ROS-dependent apoptosis. Food Funct. 2010;1(3):301-7.

13. Sun L, Luo C, Liu J. Hydroxytyrosol induces apoptosis in human colon cancer cells through ROS generation. Food Funct. 2014;5(8):1909-14.

14. Wondrak GT. Redox-directed cancer therapeutics: molecular mechanisms and opportunities. Antioxid Redox Signal. 2009;11(12):3013-69.

15. Tyagi A, Raina K, Gangar S, Kaur M, Agarwal R, Agarwal C. Differential effect of grape seed extract against human non-small-cell lung cancer cells: The role of reactive oxygen species and apoptosis induction. Nutr Cancer. 2013;65 Suppl 1:44-53.

16. Praphasawat R, Klungsupya P, Muangman T, Laovitthayanggoon S, Arunpairojana V, Himakoun L. Antimutagenicity and antioxidative DNA damage properties of oligomeric proanthocyanidins from Thai grape seeds in TK6 cells. Asian Pac J Cancer Prev. 2011;12(5):1317-21.

17. Raina K, Tyagi A, Kumar D, Agarwal R, Agarwal C. Role of oxidative stress in cytotoxicity of grape seed extract in human bladder cancer cells. Food Chem Toxicol. 2013:61:187-95.

18. Dinicola S, Pasqualato A, Cucina A, Coluccia P, Ferranti F, Canipari R, et al. Grape seed extract suppresses MDA-MB231 breast cancer cell migration and invasion. Eur J Nutr. 2014;53(2):421-31.

19. Stankovic M, Tesevic V, Vajs V, Todorovic N, Milosavljevic S, Godevac D. Antioxidant properties of grape seed extract on human lymphocyte oxidative defence. Planta Med. 2008;74(7):730-5.

20. Perde-Schrepler M, Chereches G, Brie I, Tatomir C, Postescu ID, Soran L, et al Grape seed extract as photochemopreventive agent against UVB-induced skin cancer. J Photochem Photobiol B. 2013;118:16-21.

21. Kaur M, Singh RP, Gu M, Agarwal R, Agarwal C. Grape seed extract inhibits in vitro and in vivo growth of human colorectal carcinoma cells. Clin Cancer Res. 2006;12(20 Pt 1):6194-202.

22. Chen BH, Hung MH, Chen JYF, Chang HW, Yu ML, Wan L, et al. Anti-allergic activity of grapeseed extract (GSE) on RBL-2H3 mast cells. Food Chem. 2012;132(2):968-74.

23. Yeh CC, Yang Jl, Lee JC, Tseng CN, Chan YC, Hseu YC, et al. Anti-proliferative effect of methanolic extract of Gracilaria tenuistipitata on oral cancer cells involves apoptosis, DNA damage, and oxidative stress. BMC Complement Altern Med. 2012;12(1):142.

24. Yen YH, Farooqi AA, Li KT, Butt G, Tang JY, Wu CY, et al. Methanolic extracts of Solieria robusta inhibits proliferation of oral cancer Ca9-22 cells via apoptosis and oxidative stress. Molecules. 2014;19:18721-32.

25. Chiu CC, Haung JW, Chang FR, Huang KJ, Huang HM, Huang HW, et al. Golden berry-derived 4beta-hydroxywithanolide E for selectively killing oral cancer cells by generating ROS, DNA damage, and apoptotic pathways. PLoS One. 2013;8(5):e64739.

26. Yen CY, Chiu CC, Haung RW, Yeh CC, Huang KJ, Chang KF, et al. Antiproliferative effects of goniothalamin on Ca9-22 oral cancer cells through apoptosis; DNA damage and ROS induction. Mutat Res. 2012;747(2):253-8.

27. Yeh CC, Tseng CN, Yang Jl, Huang HW, Fang Y, Tang JY, et al. Antiproliferation and induction of apoptosis in Ca9-22 oral cancer cells by ethanolic extract of Gracilaria tenuistipitata. Molecules. 2012;17(9):10916-27. 
28. Chan WH, Wu HJ. Methylglyoxal and high glucose co-treatment induces apoptosis or necrosis in human umbilical vein endothelial cells. J Cell Biochem. 2008;103(4):1144-57.

29. Aghbali A, Hosseini SV, Delazar A, Gharavi NK, Shahneh FZ, Orangi M, et al. Induction of apoptosis by grape seed extract (Vitis vinifera) in oral squamous cell carcinoma. Bosn J Basic Med Sci. 2013;13(3):186-91.

30. Masters J. False cell lines. Carcinogenesis. 2002;23(2):371.

31. Chatelain K, Phippen S, McCabe J, Teeters CA, O'Malley S, Kingsley K Cranberry and grape seed extracts inhibit the proliferative phenotype of oral squamous cell carcinomas. Evid Based Complement Alternat Med. 2011;2011:467691.

32. Shrotriya S, Deep G, Gu M, Kaur M, Jain AK, Inturi S, et al. Generation of reactive oxygen species by grape seed extract causes irreparable DNA damage leading to G2/M arrest and apoptosis selectively in head and neck squamous cell carcinoma cells. Carcinogenesis. 2012;33(4):848-58.

\section{Submit your next manuscript to BioMed Central and take full advantage of:}

- Convenient online submission

- Thorough peer review

- No space constraints or color figure charges

- Immediate publication on acceptance

- Inclusion in PubMed, CAS, Scopus and Google Scholar

- Research which is freely available for redistribution 